\title{
Analysis of the presence of glyphosate in sediments from the hydrographic basin dam of the São João stream in the municipality of Porto Nacional, Tocantins
}

Agricultural production has been one of the activities that most affect the quality of fresh water, due to accelerated urbanization, as well as the growing agricultural production in the region such as corn and soy in order to meet the high consumption demanded by the population, such activities have influenced drastically hydrographic basin conditions due to the excessive use of pesticides. Among the consequences caused are soil erosion, silting, increased production of sediments as well as water turbidity. Through studies related to sediments, it was possible to notice that their structures retain most of the chemical products, through the processes of adsorption, infiltration, and sorption in the soil. This in fact resulted in a study to assess the quality of the São João strecm hydrographic basin, which covers the cith of chemical products resulting from agricultural use through the collection of sediment samples from the São João stream dam to check the presence of glyphosate, in addition to soil particle of chemical products resulting from agricultural use through the collection of sediment samples from the São João stream dam to check the presence of glyphosate, in addition to soil particle
size characterization, for particle size classification. From the results obtained in the laboratory, it was observed that the soil presented a high granulometric variation, which despite containing size characterization, for particle size classification. From the results obtained in the laboratory, it was observed that the soil presented a high granulometric variation, which despite containing a small percentage of fines such as silt, most of the sample consists of medium sand, coarse sand and gravel responsible for $86.66 \%$ of the total sample. The result obtained an average value the manifestation of the herbicide present in the sample, contacting the vulnerability of water resources, as a result of the poor management of the hydrographic basin, in which the concentrations of agrochemical chemical glyphosate did not show results superior to those allowed by the CONAMA resolution 307/2005. However, due to the growing agricultural activity in the region, this must be periodically evaluated so that it does not reach alarming numbers, subsequently harming water quality.

Keywords: Degradation; Water; Pesticides

\section{Análise da presença de glifosato em sedimentos da barragem da bacia hidrográfica do córrego São João no município de Porto Nacional, Tocantins}

\begin{abstract}
A produção agrícola tem sido uma das atividades que mais afetam a qualidade da água doce, em decorrência da urbanização acelerada, bem como a crescente produção agrícola na região A a dos realizacão do estudo de avaliaça da qualidade da superficial. Dispondo do objetivo principal da análise das manifestações de produtos químicos decorrentes do uso agrícola através de coleta de amostras de sedimentos da barragem do córrego são João para verificação da presença de glifosato, além de caracterização granulométrica do solo para, classificação do tamanho das partículas. A partir dos resultados obtidos em laboratório, observou-se que o solo apresentou alta variação granulométrica, que apesar de conter pequeno percentual de finos como silte, a maior parte da amostra é constituída de areia média, areia grossa e pedregulho responsável por $86,66 \%$ do total da amostra. O resultado obteve valor médio de $0,02 \mu \mathrm{g} / \mathrm{L}$. Em seguida, os resultados foram comparados aos valores especificados pela legislação ambiental, em sua resolução 357/2005 do Conselho Nacional do Meio Ambiente. Os valores evidenciaram a manifestação do herbicida presente na amostra contatando a vun

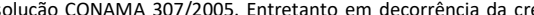
alcancem números alarmantes, prejudicando posteriormente a qualidade da água.
\end{abstract}

Palavras-chave: Degradação; Água; Agrotóxico.

Topic: Engenharia Ambiental

Reviewed anonymously in the process of blind peer.

Patricia de Oliveira Godinho (id

Instituto Tocantinense Presidente Natonio Carlos, Brasil

http://lattes.cnpq.br/7667179376835108

http://orcid.org/0000-0001-8344-8553

patriciagodinhoeng@gmail.com

Angelo Ricardo Balduino (id

Universidade Federal do Tocantins, Brasil

http://lattes.cnpq.br/8475669590774317

http://orcid.org/0000-0002-7082-2566

angelo.balduino@uft.edu.br
Received: 03/05/2020

Approved: 30/06/2020
Referencing this:

GODINHO, P. O.; BALDUINO, A. R.. Analysis of the presence of glyphosate in sediments from the hydrographic basin dam of the São João stream in the municipality of Porto Nacional, Tocantins. Nature and Conservation, v.13, n.3, p.43-51, 2020. DOI: http://doi.org/10.6008/CBPC2318-2881.2020.003.0005 


\section{INTRODUCTION}

As mentioned by Lanna (1993) the water resource is a natural, finite good that can be characterized as an elementary raw material for the survival of living beings. Thus being considered, goods of relevant value for the promotion of the quality of life in which we can notice that it is present in all the execution processes from the industry, to the demands of the civil construction.

Agricultural practices have shown high consumption of chemical substances, such as glyphosate in order to spread pests, fungi, pests and crop plants, in order to increase productivity, associated with soil interventions that cause sediment contamination, which in turn present characteristics of retaining and transporting toxic substances contaminating water resources (VEIGA et al., 2006).

The vulnerability of the aquatic environment to pesticide contamination occurs at the expense of the ecosystem's resistance characteristics, duration and contaminant type (PASCHOAL, 2002). According to the same author, the interaction of pesticides with the aquatic environment essentially depends on factors such as, for example, the proximity of sources of pollution, in addition, it relies on the surface runoff of contaminated particles, as well as leaching.

It is defined by pesticides, a chemical substance used in the extermination of pests that affect agricultural crops, the most common of which are organophosphates and carbamates Veiga et al. (2006) such reagents usually serve effectively, maintaining the integrity of the plantation, however their contamination also occurs in sediments through the infiltration of the soil, causing damage in unforeseen places with the use of substances. Poor management of the hydrographic basin, as a result of agricultural activity, has resulted in the manifestation of glyphosate present in sediments, which in turn, can generate a series of disorders in the organism in contact with living beings (PAIVA, 2017).

The municipality in which the hydrographic basin in question is located has made a relevant contribution to the increase in agricultural production in the state, which in turn has a high development for the agricultural industry by obtaining half of the territory $50.25 \%$ of areas suitable for culture, presenting an increase in production of $240 \%$ in recent years, standing out today as the state with the highest grain production in the northern region of Brazil, resulting in an excessive use of pesticides.

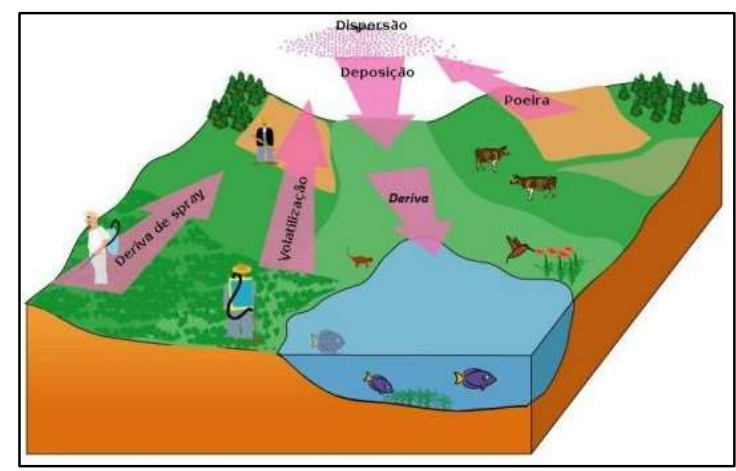

Figure 1: Scheme of passage of pesticides in the environment. Source: Rebelo (2013).

For Amarante Júnior et al. (2002) glyphosate has been used in several types of cultures, in which its 
action in water, its use is characteristic and places of increase in values referring to $\mathrm{pH}$ and temperature. Figure 1 shows the diagram of the destination of the pesticide from the application in the environment, which may present adsorption infiltration processes in the soil, influenced by the size of the particles and the temperature of the environment.

This work aims to present the study related to the determination of glyphosate concentrations present in the sediments of the supply dam of the São João river basin, Porto Nacional - TO by correlating the values obtained in the study with the standards determined by legislation environmental and technical literature. Chemical substance called glyphosate belonging to the family of herbicides, of non-selective characteristics, that is, it attacks proportionally to any species of plants, depending on environmental conditions, and volume used. As for its classification, it is determined as post-emergent since the application is carried out after germination (BENETTI, 2011). Figure 2 represents the chemical structure of glyphosate.

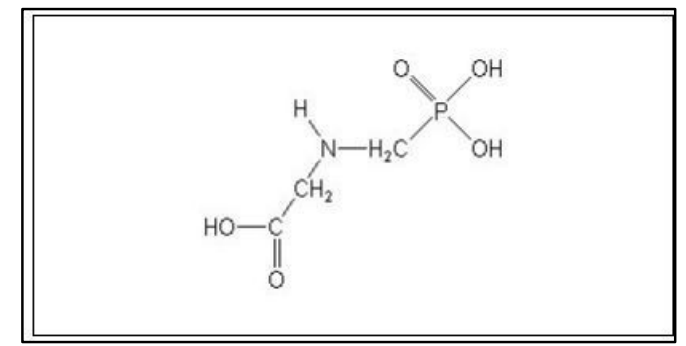

Figure 2: Glyphosate chemical structure (CH3C3H8NO5P).

Sediments are solid particles, resulting from the breakdown of different types of rocks, by the weathering process, which in turn can present themselves as a physical or biological chemist (PINTO, 2006). These sediments, their movement depends on the transport agents, in which the most common are wind and rainwater commonly identified as wind and rain.

As pointed out by Silva et al. (2017) erodibility is the ability of a given soil to resist the causes of erosion, these processes are often defined by the agent in which they caused the occurrence, this being called water erosion those in which they arise as a result of precipitation, wind erosion, arising from the action of the wind, as well as anthropic erosion caused by the action of man.

The high toxicity of certain pesticides, such as glyphosate, are one of several factors that favor and condition the emergence of negative consequences both for the environment and for living beings. Several researches show people who have contact with the substance, developing a predisposition to contagion with the most varied diseases. Contamination can occur with food consumers from agricultural production, as well as product applicators and the community in general (SILVA, 2006). Exposure to the substance can cause respiratory problems, pulmonary dysfunction, being able to present, in more severe cases, muscle disorders and gastrointestinal problems.

\section{METHODOLOGY}

\section{Study and Experiment Area}


The study was carried out in the Ribeirão São João watershed, which has an area of approximately $82 \mathrm{~km}^{2}$, located in the state of Tocantins, between the coordinates $10^{\circ} 46^{\prime} 43^{\prime \prime}$ and $20^{\circ} 41^{\prime} 20^{\prime \prime}$ south latitude and between the meridians $48^{\circ} 14^{\prime} 16^{\prime \prime}$ and $48^{\circ} 24^{\prime} 51^{\prime \prime}$ west longitude, southeast of the municipality of Porto Nacional Tocantins. As shown in figure 3.

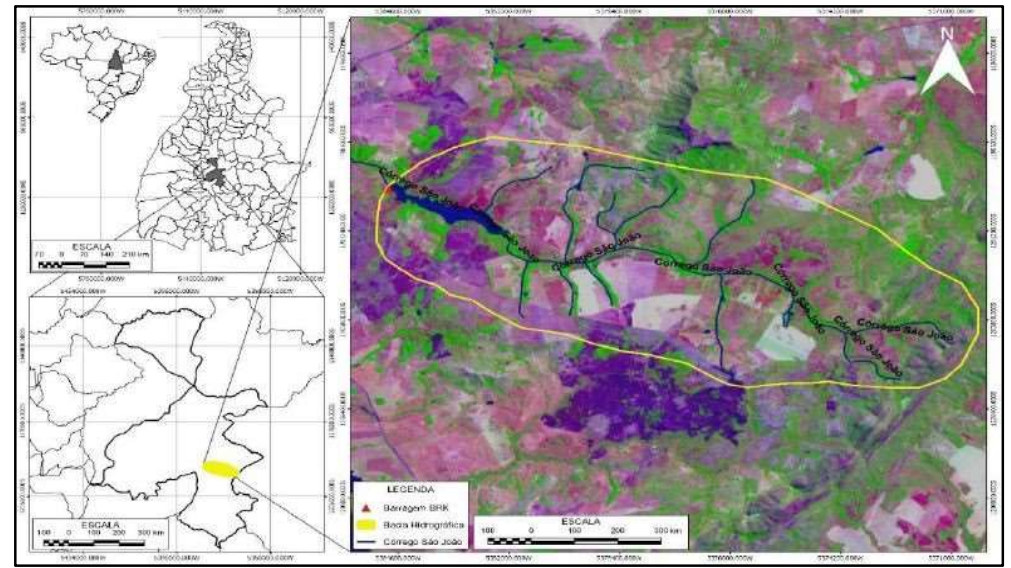

Figure 3: Location map of the Ribeirão São João River Basin. Source: Balduino (2018).

The methodology was based on a case study, and sediment evaluation through collections and analyzes related to ecotoxicology, in order to observe the presence of glyphosate in solid sediment particles. To this end, procedures such as assessment of points in the hydrographic basin were carried out through field visits, with the help of related bibliographies.

\section{Field Methodology}

\section{Collection of sediment samples}

From the data obtained through the bathymetric survey, predict which places of greatest sediment accumulation and, from there, perform the collection at the indicated points, the collection point was defined from the coordinate values: $10^{\circ} 42^{\prime} 46^{\prime \prime} \mathrm{S} 048^{\circ} 22^{\prime} 37^{\prime \prime} \mathrm{W}$ referring to the collection point. The collection point was identified from the coordinates obtained by GPS that are presented in the following values. Figure 4 shows the soil collection point according to the coordinates previously described.

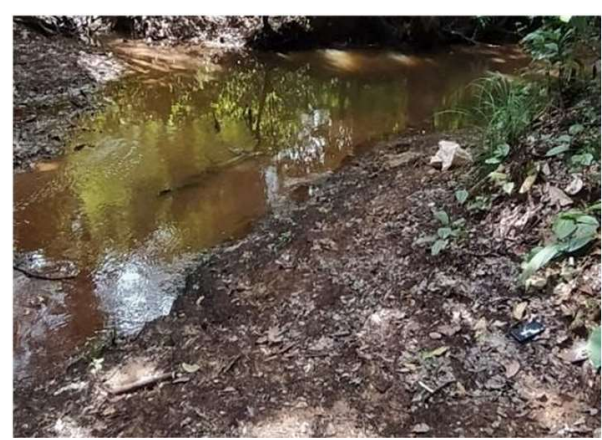

Figure 4: Location of the sediment collection point.

\section{Laboratory Methodology}

The samples were collected in flasks, packed in thermal boxes containing ice, and were sent to the 
Chemistry/Limnology Laboratory of the Federal Institute of Education, Science and Technology of Tocantins (IFTO), campus of Porto Nacional, Tocantins.

\section{Specific mass of solids}

In the process of determining soil granulometry, the standard indicates that the specific mass test of the solids is initially carried out, which in turn must be carried out on two samples to verify the results and choose the values from the average of the obtained values. Figure 5 shows the stage of the soil specific mass test.

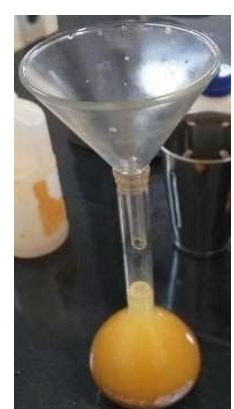

Figure 5: Test stage of specific gravity of the soil.

\section{Granulometry Analysis}

After determining the specific mass of the solids, the joint granulometry test was carried out, covering the stages of sedimentation and sieving the sample. According to the sieve indications by ABNT NBR $7181 / 2016$. The result of this test is represented by the soil size curve.

\section{ABNT NBR Sedimentation (7181/2016)}

For the sedimentation test, a sample of the passing sieve test was used in the $2.0 \mathrm{~mm}$ sieve according to the standard specifications, with a weight of $120 \mathrm{~g}$, taking into account the characteristics of the soil as sandy, in which it was immersed for 12 hours with deflocculant (sodium hexametaphosphate solution). Next, in figure 6 , the representation of the stages of the sedimentation test.

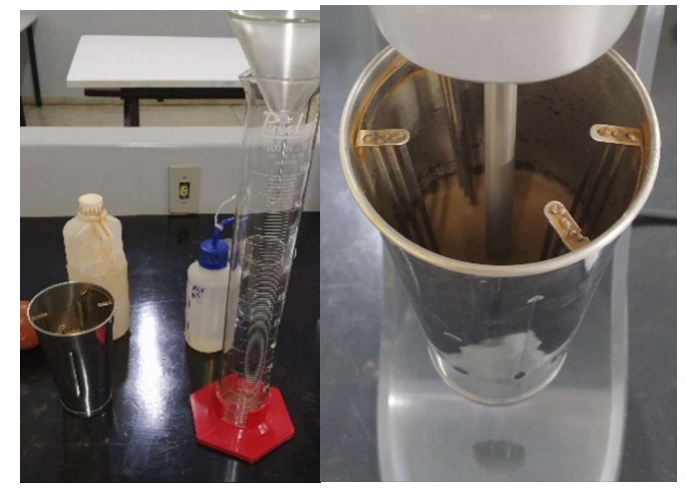

Figure 6 : Step by step of the sedimentation preparation and execution process.

\section{ABNT NBR granulometry test (7181/2016)}

To perform the granulometric analysis of the bottom sediments, the sample was prepared according 
to the specifications of ABNT NBR 6457/2016. The results were obtained by means of a granulometric curve that indicates the percentage fraction of each material as well as its dimensions in millimeters in which it is possible to determine the predominant soil type. Taking into account that smaller soils are more favorable when glyphosate is identified. As can be seen in figure 7, the representation of the joint granulometric analysis test procedures.

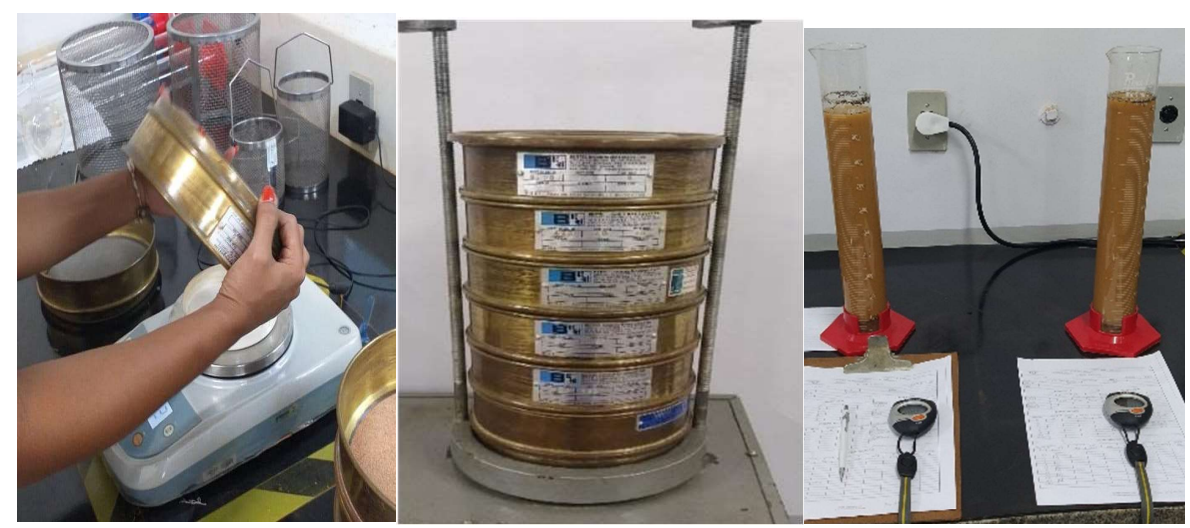

Figure 7: Granulometry test procedures.

Table 1: Limits of soil fractions by grain size. ABNT

\begin{tabular}{|l|l|}
\hline Fraction & Limits defined by ABNT \\
\hline Contact & From $25 \mathrm{~cm}$ to $1 \mathrm{~m}$ \\
\hline Stone & From $0.76 \mathrm{~cm}$ to $25 \mathrm{~cm}$ \\
\hline Boulder & From $4.8 \mathrm{~mm}$ to $7.6 \mathrm{~cm}$ \\
\hline Coarse sand & From $2 \mathrm{~mm}$ to $4.8 \mathrm{~mm}$ \\
\hline Medium sand & $0.42 \mathrm{~mm}$ to $2 \mathrm{~mm}$ \\
\hline Thin sand & From $0.05 \mathrm{~mm}$ to $0.42 \mathrm{~mm}$ \\
\hline Silte & From $0.005 \mathrm{~mm}$ to $0.05 \mathrm{~mm}$ \\
\hline Clay & Less than $0.005 \mathrm{~mm}$ \\
\hline
\end{tabular}

Source: Pinto (2006).

\section{Analysis of glyphosate sediment samples}

The detection of glyphosate was carried out in the laboratory by means of CG/EM (gas chromatograph with mass detector) using capillary columns containing several stationary phases and using selective detectors the samples of $(20 \mathrm{~g})$ were dried in an oven with circulation of air at 25 으, sieved in a 2 $\mathrm{mm}$ mesh and the glyphosate was extracted through aqueous acidic solution.

\section{Parameters determined by conama resolution no. 357}

After the analysis, the values found were compared to those provided by the relevant legislation defined by Federal Law 9,433 of 1997, which specifies the limit values of glyphosate present in the water that is used for public supply as we can see in table 2. In order to see if the results submitted comply with the relevant legislation.

Table 2: Parameter limits determined by CONAMA resolution N. 357 (2005).

\begin{tabular}{|l|l|l|}
\hline Parameters & CONAMA determination No. 357 & Value (limit) \\
\hline Glyphosate & Values must not exceed & $65 \mu \mathrm{g} / \mathrm{L}$ \\
\hline
\end{tabular}




\section{RESULTS AND DISCUSSION}

\section{Results of test performed in laboratory}

From laboratory tests, it was possible to observe that most of the soil's granulometry is basically composed of sand, with particle size varying between $0.05 \mathrm{~mm}$ and $4.8 \mathrm{~mm}$. Classifying the material as sandy soil. As can be seen in Table 3, which presents the results of the granulometric characterization tests obtained from them.

Table 3: Result of soil granulometric characterization test.

\begin{tabular}{|l|l|}
\hline Laboratory tests & Results \\
\hline Specific Mass of Solids Granulometry & $2,692 \mathrm{~g} / \mathrm{cm}^{3}$ \\
\hline Clay (less than $0.005 \mathrm{~mm})$ & $0 \%$ \\
\hline Silt (0.005mm to $0.05 \mathrm{~mm})$ & $6,20 \%$ \\
\hline Fine Sand (0.05mm to 0.42mm) & $8,84 \%$ \\
\hline Medium Sand (0.42mm to $2 \mathrm{~mm})$ & $27,78 \%$ \\
\hline Coarse Sand (2mm to $4.8 \mathrm{~mm})$ & $46,85 \%$ \\
\hline Boulder (4.8mm to $76 \mathrm{~mm})$ & $12,03 \%$ \\
\hline
\end{tabular}

The test generated a granulometric curve in order to represent the amount of soil according to the size of the particles, as can be seen in figure 8 .

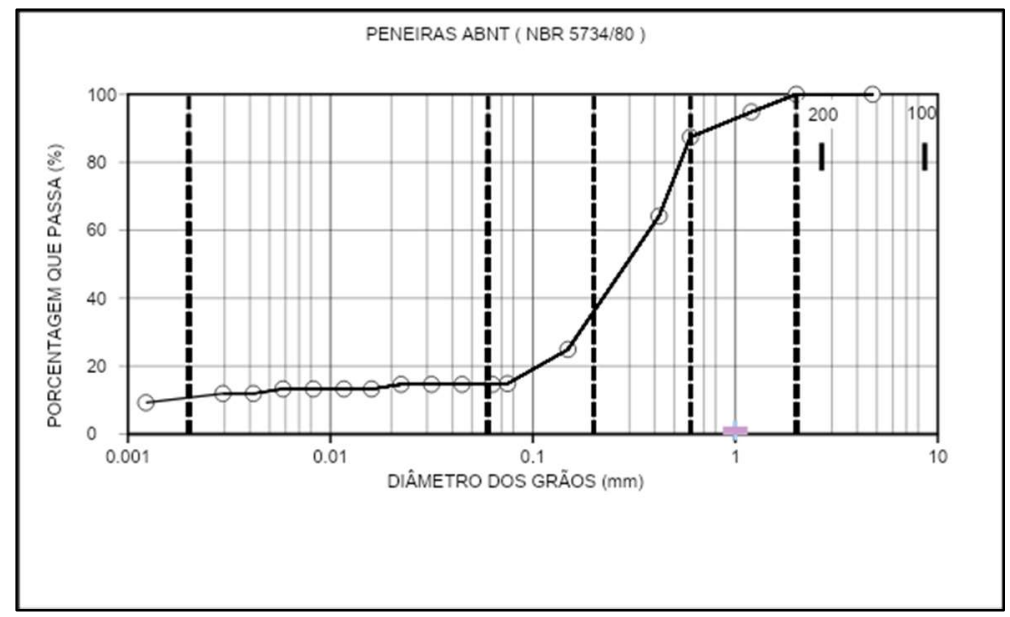

Figure 8: Particle size curve.

The sandy soil, as it has larger particles and presents itself in poorly graduated structures, being commonly made up of particles of the same size, which favors the number of voids present in the soil and consequently the permeability speed of the fluid or substance. It can infiltrate through its particles with greater ease, which interferes with the duration of contact of the glyphosate with the surface reaching the groundwater quickly (PINTO, 2006). However, predominant areas of cohesive clays, the process occurs in an opposite way, with low permeability, due to the arrangement of the particle structures (PINTO, 2006).

In the author's considerations, the process of infiltration of fluids in the submerged layers of soil occurs gradually according to the characterization of the soil and the size of the particles, this behavior occurs because the permeability of the soil is directly linked to the volume of voids gifts. However, areas in which they have larger grained soils have greater permeability capacity of substances reaching the hydrographic basin with greater ease (SANTOS, 2016). 


\section{Result Analysis of Glyphosate in Sediments}

The glyphosate pesticide ( $\mathrm{CH} 3 \mathrm{C} 3 \mathrm{H} 8$ NO $5 \mathrm{P}$ ) is commonly used for the extermination of harmful pests that show satisfactory results, however it exposes the environment to undesirable effects. Based on this, the laboratory studies showed results regarding the amount of herbicide present in the sediments in order to verify the possibility of contamination of the hydrographic basin under study Paiva (2017). According to the analysis performed in the laboratory using the chromatograph, the values obtained were presented, as can be seen in Table 4.

Table 4: Result of glyphosate analysis.

\begin{tabular}{|l|l|}
\hline Sample & Result \\
\hline 1 & $0,02 \mu \mathrm{g} / \mathrm{L}$ \\
\hline
\end{tabular}

With respect to the result of the glyphosate analysis, the analyzes indicated manifestations of the glyphosate substance present in the sediment, showing the contamination. The Brazilian legislation determines in its CONAMA resolution N. 307 (2005) that the values must not exceed $0.065 \mu \mathrm{g} / \mathrm{L}$. The study point showed $0.02 / \mathrm{L}$. It is estimated that the value was influenced by the size of the particles, considering that soils made up of clay particles, retain substances more easily.

The studies by Silva (2006) presents toxicology, a science that studies the behavior and interaction of the chemical substance in the body, informing the negative results in humans, based on the herbicides being part of the group of chemical agents responsible for presenting a degree of toxicity, which causes damage to health. Based on these values, they must be observed periodically, due to the expansion of agricultural activity in the region, which in turn causes poor management of the hydrographic basin, exposing water resources to contact with contaminants. Even though the result regarding the present glyphosate substance has presented within the limit allowed by Brazilian legislation, the simple occurrence of manifestation in contact with water, presents the vulnerability of the hydrographic basin to the exposure of degrading agents to human health.

\section{CONCLUSIONS}

The analysis relevant to the manifestation of glyphosate present in the sediments of the reservoir, was of paramount importance for the evaluation of the consequences arising from the advance of agricultural production in the region, being able to observe how these results can affect the quality of the water supply in the city of Porto Nacional - TO.

The activity of identifying soil granulometry contributed positively to the characterization of the sediment in order to verify the existence of clay soils, implying greater ease of retention by the agrochemical glyphosate. The granulometry result pointed to a sandy material, based on the granulometric analysis of the material, the soil is made up of larger granulation particles between $0.05 \mathrm{~mm}$ to $76 \mathrm{~mm}$, with $43.5 \%$ of coarse sand. However, the results may change in other parts of the basin, since the use and occupation of the soil exposes water resources to greater contact with the contaminating source. In addition, areas where the soil 
Analysis of the presence of glyphosate in sediments from the hydrographic basin dam of the São João stream in the municipality of Porto Nacional, Tocantins

has a higher granulation have a greater permeability capacity of substances reaching the hydrographic basin with greater ease, and although the results do not present excessive values, even so, due to the type of soil, it may favor the contact of the soil substance with water (SILVA, 2006).

In addition, for Balduino (2018) sediments are the final destination for accumulation of agrochemicals due to their ability to retain substances from agricultural activities. Agricultural management practices show the direct exposure of the hydrographic basin with herbicide, as well as the reduction of vegetation, which in turn decreases the capacity to retain substances, causing undesirable behaviors in water resources, such as silting.

Although the result respects the standard established by CONAMA resolution 307/2005, this must be observed so that it does not present harmful values. Subsequently contributing to the variation of $\mathrm{pH}$ and water turbidity, factors that affect negatively, reducing water quality, and causing a propensity to the emergence of diseases.

\section{REFERENCES}

ABNT. Brazilian Association of Technical Standards. ABNT NBR 7181: 2016 SOLO: Particle size analysis. ABNT, 1984.

ABNT. Brazilian Association of Technical Standards. ABNT NBR 6457: 2016 SOIL SAMPLES: Preparation for compaction and characterization tests. ABNT, 1986.

AMARANTES JUNIOR, O. P. A.; SANTOS, T. C. R.; BRITO, N. M.; RIBEIRO, M. L.. Glyphosate: Properties, Toxicity, Uses and Legislation. São Paulo, 2002.

BALDUINO, A. R.; SANTOS, M. G.; SOUZA, L. B.; LIMA, D. P.; CARVALHO, A. P.. Hydric balance and climatic classification of the city of Porto Nacional, state of Tocantins, inserted in the Legal Amazon, Brazil. Revista Ibero-American Journal of Environmental Sciences, v.5, n.3, 2018.

BRASIL. Law n.9,433, of January 8, 1997. Institutes the National Water Resources Policy, creates the National Water Resources Management System, regulates item XIX of art. 21 of the Federal Constitution. Brasília: DOU, 1997.

BENETTI, F.. Development and validation of methodology for multi-residue determination of glyphosate and AMPA via CG-EM in environmental samples. São Carlos, 2011.

CONAMA. National Environment Council. Resolution n. 357: Classification of water bodies and environmental guidelines for their classification. CONAMA, 2005.

LANNA, A. E.. Hydrology: Science and application. Porto Alegre: UFRGS, 1993.
PAIVA, D. C. A. C.. Effect of phosphorus concentration on aerobic degradation of glyphosate in a fixed bed reactor. Goiânia: Federal University of Goiás, 2017.

PASCHOAL, C. M. R. B.. Ecotoxicological assessment of sediments in a reservoir in the Tietê river basin, SP, with emphasis on the application of the AIT study: Assessment and identification of toxicity. São Carlos, 2002.

PINTO, C. S.. Basic Course in Soil Mechanics. São Paulo: Oficina de Texts, 2006.

REBELO, R. M.. Development of a data platform for environmental risk assessment of pesticides in Brazil using the pesticide root zone model (PRZM). Brasília, 2013.

SANTOS, J. S.. Remediation of soil contaminated with pesticides by treatment with gamma radiation. São Paulo, 2009.

SILVA, P. H. M.; MARTINS, R. Í. M.. Application development to assist in registering linear erosions in an urban environment. Goiânia, 2017.

SILVA, V. M.. The use of pesticides in coffee against the risk of health workers in rural municipality of Cacoal/RO (Brazil). Brasília: University of Brasília, 2006.

VEIGA, M. M.; SILVA, D. M.; VEIGA, L. B. E.; FARIA, M. V. C.. Analysis of contamination of water systems by pesticides in a small community in southeastern Brazil. Public Health Notebook, 2006.

A CBPC - Companhia Brasileira de Produção Científica (CNPJ: 11.221.422/0001-03) detém os direitos materiais desta publicação. Os direitos referem-se à publicação do trabalho em qualquer parte do mundo, incluindo os direitos às renovações, expansões e disseminações da contribuição, bem como outros direitos subsidiários. Todos os trabalhos publicados eletronicamente poderão posteriormente ser publicados em coletâneas impressas sob coordenação da Sustenere Publishing, da Companhia Brasileira de Produção Científica e seus parceiros autorizados. Os (as) autores (as) preservam os direitos autorais, mas não têm permissão para a publicação da contribuição em outro meio, impresso ou digital, em português ou em tradução. 